\title{
Philosophiques
}

\section{De l'éthique environnementale à l'écologie politique Apories et limites de l'éthique environnementale}

\section{François Blais et Marcel Filion}

Volume 28, numéro 2, automne 2001

URI : https://id.erudit.org/iderudit/005664ar

DOI : https://doi.org/10.7202/005664ar

Aller au sommaire du numéro

\section{Éditeur(s)}

Société de philosophie du Québec

\section{ISSN}

0316-2923 (imprimé)

1492-1391 (numérique)

Découvrir la revue

Citer cet article

Blais, F. \& Filion, M. (2001). De l'éthique environnementale à l'écologie politique Apories et limites de l'éthique environnementale. Philosophiques, 28(2), 255-280. https://doi.org/10.7202/005664ar

\section{Résumé de l'article}

Les objectifs de l'éthique environnementale et de l'écologie politique diffèrent. L'éthique environnementale, telle qu'elle s'est développée ces dernières années, a cherché, entre autres, à préciser la nature du lien entre l'Humain et la Nature. Cette démarche philosophique ne permet pas de définir les obligations environnementales valables pour tous dans une situation de pluralisme axiologique. Ce texte poursuit deux objectifs. À des fins d'illustration, nous présentons tout d'abord quatre approches représentatives de l'éthique environnementale contemporaine (Section 2). Nous rappelons les principales objections soulevées à leur endroit et le cul-de-sac théorique ou pratique dans lequel elles se trouvent engagées. Nous entreprenons ensuite (Section 3) de fournir l'esquisse d'une alternative que nous appelons simplement « l'écologie politique ». Nous en dressons les contours et surtout la spécificité par rapport à l'éthique environnementale. Les objets de l'éthique environnementale et de l'écologie politique sont peutêtre complémentaires mais certainement pas coextensifs. 


\title{
De l'éthique environnementale à l'écologie politique Apories et limites de l'éthique environnementale
}

\author{
FRANÇOIS BLAIS \\ Département de science politique \\ Université Laval \\ françois.blais@pol.ulaval.ca \\ MARCEL FILION \\ Département de science politique \\ Université Laval \\ marcel.filion@pol.ulaval.ca
}

\begin{abstract}
RÉSUMÉ. - Les objectifs de l'éthique environnementale et de l'écologie politique diffèrent. L'éthique environnementale, telle qu'elle s'est développée ces dernières années, a cherché, entre autres, à préciser la nature du lien entre l'Humain et la Nature. Cette démarche philosophique ne permet pas de définir les obligations environnementales valables pour tous dans une situation de pluralisme axiologique. Ce texte poursuit deux objectifs. À des fins d'illustration, nous présentons tout d'abord quatre approches représentatives de l'éthique environnementale contemporaine (Section 2). Nous rappelons les principales objections soulevées à leur endroit et le cul-de-sac théorique ou pratique dans lequel elles se trouvent engagées. Nous entreprenons ensuite (Section 3) de fournir l'esquisse d'une alternative que nous appelons simplement «l'écologie politique ». Nous en dressons les contours et surtout la spécificité par rapport à l'éthique environnementale. Les objets de l'éthique environnementale et de l'écologie politique sont peutêtre complémentaires mais certainement pas coextensifs.
\end{abstract}

ABSTRACT. - The objectives of environmental ethics and political ecology differ. Environmental ethics, such as it developed in the last few years, sought, among other things, to specify the nature of the link between Human Beings and Nature. This philosophical approach does not allow the definition of environmental obligations to be imposed on all in the context of moral pluralism. This article pursues two goals. To illustrate our argument, we will first present four representative approaches to contemporary environmental ethics (Part 2). We will recall the principal objections raised against them and the theoretical and practical dead-ends in which they culminate. We will then (Part 3) propose the outline of an alternative which we call political ecology. We will then trace its boundaries and mainly its particularities in relation to environmental ethics. The objects of environmental ethics and of political ecology may be complementary but they are certainly not coextensive.

\section{Introduction :}

La pensée écologiste contemporaine est peuplée d'une multitude de doctrines éparses, controversées, parfois irréconciliables, parfois complémentaires. Mal- 
gré leurs différences, plusieurs de ces doctrines écologistes défendent une interprétation «culturaliste » et "éthique » des causes responsables de la détérioration globale de l'environnement. Un diagnostic "culturaliste " ou " éthique » s'attarde en priorité aux changements dans les manières de penser plutôt que de faire. Il entraîne donc des solutions englobantes qui, dans le cas de la pensée écologiste, visent toutes une redéfinition générale de notre façon de penser nos rapports avec la Nature. Dans ce texte, nous appellerons " éthique environnementale » les doctrines écologistes qui proposent, pour solutionner la crise écologique, une révision en profondeur de ce rapport dans ses dimensions philosophique, esthétique, existentielle ou même religieuse.

Nous poursuivrons deux objectifs dans les pages qui suivent. Le premier (Section 2) est de distinguer quatre des principales approches de l'éthique environnementale contemporaine. Dans un souci de synthèse qui laisse toutefois apprécier leur diversité, nous tâcherons de rappeler brièvement leur apport respectif, les objections récurrentes soulevées à leur encontre et nous terminerons notre exposé en identifiant, pour chacune, le cul-de-sac théorique ou politique dans lequel elle se trouve engagée aujourd'hui. Ces difficultés, c'est là notre première thèse, ne sont pas étrangères au projet même des doctrines normatives qui ont pour première préoccupation d'argumenter en faveur de la reconnaissance d'une valeur intrinsèque à des vecteurs naturels autres qu'humains.

Nous entreprendrons ensuite (Section 3) de fournir l'esquisse d'une alternative écologiste générale qui n'aurait pas, elle, à affronter les problèmes que nous décelons dans l'éthique environnementale. Cette alternative, nous l'appelons simplement "l'écologie politique ". Nous en dresserons les contours et surtout la spécificité par rapport à l'éthique environnementale. Notre seconde thèse générale consiste à soutenir que les objets de l'éthique environnementale et de l'écologie politique sont complémentaires mais non coextensifs. Lorsque l'un et l'autre sont en conflit, il nous faut donc trancher sur les principes à privilégier. La définition de l'écologie politique que nous retenons spécifie que dans de telles circonstances, nous devrions mettre en valeur ses principes au détriment, s'il le faut, des injonctions de quelque éthique environnementale ${ }^{1}$.

1. La distinction éthique environnementale-écologie politique ne doit pas être confondue avec une autre distinction, bien connue de ceux qui fréquentent le champ, entre écologisme et environnementalisme. Andrew Dobson suggère pour ce dernier duo la définition suivante :

(...) The principal difference between the two is that ecologism argues that care for the environment (a fundamental characteristic of the ideology in its own right, of course) presupposes radical changes in our relationship with it, and thus in our mode of social and political life. Environmentalism, on the other hand, would argue for a 'managerial' approach to environmental problems, secure in the belief that they can be solved without fundamental changes in present values or patterns of production and 


\section{2. Évolution et critique des débats en éthique environnementale}

\subsection{L'écothéologie : les racines religieuses du problème et les moyens d'y remédier}

Présentation - Les êtres humains ont toujours senti le besoin de comprendre et de définir la place qu'ils occupent au sein de leur environnement naturel et, de façon plus globale, au sein de l'univers. Chez les populations archaïques, la relation Humain-Nature fut, dit-on, envisagée d'abord à travers ses dimensions mythologique et religieuse, par l'entremise de cultes et de rites ancrés dans des présupposés animistes. Dans la plupart des sociétés traditionnelles, les éléments naturels sont perçus comme habités d'esprits ou de divinités, ce qui commande de facto le respect et la crainte de la Nature prise dans son ensemble ${ }^{2}$.

Ce caractère sacré de la Nature, et le respect qu'il suscite, se serait perdu avec le temps. La thèse centrale des partisans de l'écothéologisme consiste à présenter la tradition judéo-chrétienne comme la première responsable de ce changement fort important. Comment cela a-t-il pu se faire ? Les écothéologistes accusent le christianisme d'avoir propagé l'idée d'une temporalité linéaire qui rompt avec le modèle cyclique des Anciens et qui suggère, en contrepartie, la vision d'une histoire en marche ascendante vers un point final d'accomplissement représenté par le jugement dernier. Cette idée aurait eu pour effet d'instiller dans la mentalité occidentale l'idéal d'un progrès continu tributaire, entre autres, de la mainmise humaine sur l'environnement. La conjonction de la science et de la technologie modernes aurait ensuite justifié l'humanité à exercer une pression et un contrôle sans précé-

production and consumption. (Dobson, Andrew, Green Political Thought.

An Introduction, London, Unwin Hyman, 1990, p. 13).

Il n'est pas du tout sûr que les approches en question soient aussi exclusives que le laissent entendre Dobson et bien d'autres. Notre thèse est plutôt à l'effet que ce qui divise le plus entre eux les promoteurs de la pensée écologiste n'est pas le type de moyens à utiliser pour venir à bout des défis environnementaux, bien que ce soit parfois le cas, mais surtout la façon dont ils conçoivent le rôle et le statut d'une théorie normative face à la protection de l'environnement. Il est difficile de penser que les écologistes parmi les plus radicaux puissent s'opposer à une attitude de saine gestion à l'égard des ressources de l'environnement.

Concernant la distinction entre écologisme et environnementalisme, voir aussi : Naess, Arne, “ The Shallow and the Deep, Long Range Ecology Movement : A Summary ”, Inquiry, 16, 1973, p. 95-100, où l'auteur distingue entre une tentative superficielle (shallow) et une autre profonde (deep) de résoudre les problèmes environnementaux.

2. Pour une compréhension plus détaillée de l'évolution des relations entre l'être humain et la Nature au cours des siècles, voir : Attfield, Robin, The Ethics of Environmental Concern, New York, Columbia University Press, 1983 ; Glacken, Clarence J., Traces on the Rhodian Shore, Nature and Culture in Western Thought from Ancian Times to the End of Eighteenth Century, Berkeley, University of California Press, 1967 ; Turner, B. L., The Earth as Transformed by Human Action, Cambridge, Cambridge University Press, 1991. 
dent sur l'ensemble du monde naturel en le mobilisant au service de besoins humains en pleine expansion et surtout incontrôlés.

L'historien américain Lynn White fut le tout premier à porter de telles accusations dans un texte devenu maintenant célèbre et publié originairement dans la revue Science $^{3}$. White y soutenait que le changement de perspective introduit par le judéo-christianisme avait ouvert la porte au " désenchantement du monde ", au matérialisme et à un nouveau dualisme Matière-Esprit aux effets écologiques délétères; sa condamnation repose alors sur des passages des Écritures incriminants à ses yeux. Le plus cité demeure certes ce célèbre extrait de la Genèse où il est dit que l'Humain détient un statut particulier et privilégié par rapport au reste de la Création :

Créons l'homme à notre image, à notre ressemblance, et qu'il domine sur les poissons de la mer, les oiseaux du ciel, les bestiaux, toutes les bêtes sauvages et toutes les bestioles qui rampent sur la terre. Dieu créa l'homme et la femme à son image, les bénit et leur dit : "Soyez féconds, multipliez-vous, emplissez la terre et soumettez-la ; dominez sur les poissons de la terre, les oiseaux du ciel et tous les animaux qui rampent sur la terre ${ }^{4}$.

Cet extrait ne peut laisser aucun doute pour White : le statut de l'Humain sur cette Terre n'est pas le même que celui des autres espèces. L'Homme dominerait ainsi la Création et il ne peut être gêné à l'idée de l'asservir pour réaliser ses fins. La crise environnementale n'est que le triste constat de cette mainmise aveugle et irresponsable de l'Homme sur la Nature qui l'a enfanté.

Comment pouvons-nous maintenant changer cet état de choses ? Une alternative s'ouvre à notre civilisation si l'on suit la littérature écothéologiste. La première solution passe par la valorisation en Occident de traditions religieuses différentes, en particulier orientales. En effet, le bouddhisme zen, le taoïsme, l'hindouisme, le jaïnisme et le shintoïsme sont considérés par la plupart des écothéologistes comme autant d'expériences religieuses intrinsèquement plus respectueuses de l'environnement puisqu'elles véhiculent une vision harmonieuse de l'univers naturel, une vision nettement plus " écologiste » où les idées d'interdépendance et d'équilibre entre toutes les composantes de la Nature occupent une place de choix ${ }^{5}$. Mais White luimême croit que si les religions orientales peuvent nous fournir de précieux enseignements, l'idée d'une transplantation de cet univers de croyances à une

3. White, Lynn, "The Historical Roots of Our Ecological Crisis ", Science, 155, p. 1203-1207, texte reproduit dans Vandeveer, Donald et Christine Pierce, dir., Environmental Ethics and Policy Book, Belmont, Wadsworth Publishing Company, 1993, p. 45-51.

4. La Genèse, I : 26-29.

5. Il n'y a qu'à penser, pour fins illustratives, aux notions de karma et de réincarnation développées par l'hindouisme, qui impliquent une conception de la vie humaine comme partie prenante d'une vaste chaîne biologique où le karma de chaque être vivant est toujours susceptible de se réincarner sous la forme de n'importe quel autre être dans la Nature, ce qui ne peut manquer d'inculquer à l'esprit un sens aigu d'appartenance à un ensemble qui le dépasse. 
culture aussi différente que la nôtre est peu envisageable. La religion n'est de toute façon pas une chose que nous choisissons comme on choisit une maison ou un téléviseur! C'est pourquoi l'auteur prône la recherche de solutions plus réalistes et surtout moins éloignées de nos propres traditions. Quoi qu'il en soit, White accepte aussi qu'il puisse exister des interprétations alternatives et plus écologiques de la Bible, des interprétations plaçant plutôt l'accent sur le rôle de gardien bienveillant de la Création que Dieu aurait confié à l'humanité. Il privilégie pour cette raison, comme d'autres écothéologistes, de raviver le témoignage spirituel d'enseignements malheureusement oubliés par l'Eglise, notamment ceux de François d'Assise, saint de tous les écologistes ${ }^{6}$.

Peu importent les solutions envisagées, les thèses culturalistes des écothéologistes ont suscité de vifs débats. Les historiens leur ont tout d'abord reproché de simplifier, de manière parfois extravagante, les rapports complexes et diffus qu'entretiennent des réalités culturelles aussi difficiles à départager que religions, sciences, technologies, modernité, etc. Cet avertissement vaut, a fortiori, dans une ère où la laïcité a fortement sapé l'influence du religieux sur les modes de vie et où il est difficile de lui accorder un rôle social aussi prépondérant que par le passé ${ }^{7}$.

White ne rejette pas la plausibilité de cette réplique, mais il insiste néanmoins pour que l'on ne marginalise pas l'influence prédominante du christianisme sur la culture moderne occidentale :

The victory of Christianity over paganism was the greatest psychic revolution in the history of our culture. It has become fashionable today to say that, for

Ou encore, qu'il sutfise d'évoquer la perpétuelle oscillation du ying et du yang, qui permet au taoïsme de percevoir la Nature, quelle que soit la forme qu'elle revête, comme un lieu sans cesse traversé par un flux d'énergie alternant constamment entre le positif et le négatif, la vie et la mort, et qui unit ainsi la totalité du vivant dans un vaste continuum intégré d'échanges. Ces façons de voir, fort actives dans la vision du monde dominante en Orient, appelleraient une attitude humaine de "saine humilité " envers le reste de la Nature, en privilégiant l'interdépendance de tous les éléments plutôt que la réalisation des composantes individuelles, et en remplaçant le concept de progrès continu par ceux de cycle, de retour, de pendule. Pour une présentation de ces idées, voir, entre autres : Chaitanya, Krishna, «A Profounder Ecology : The Hindu View of Man and Nature " The Ecologist, 13, 1983, p. 127-135 ; Hargrove, Eugene C., dir., Religion and Environmental Crisis, Athens, University of Georgia Press, 1986 ; Nash, Roderick Frazier, The Rights of Nature. A History of Environmental Ethics, Madison, The University of Wisconsin Press, 1989, p. 112-120 ; Rolston, III, Holmes, "Can the East Help the West to Value Nature », Philosophy East and West, 37, 1987, p. 172-190.

6. Voir : White, Lynn, "The Historical Roots of Our Ecological Crisis ", p. 50-51; pour des développements supplémentaires sur les conceptions de la Nature de François d'Assise, voir également l'ouvrage fouillé de Sorrell, Roger D., St. Francis of Assisi and Nature : Tradition and Innovation in Western Attitudes Toward the Environment, New York, Oxford University Press, 1988.

7. Voir : Attfield, Robin, The Ethics of Environmental Concern, p. 20-33 et 67-87; Passmore, John, Man's Responsibility for Nature, London, Duckworth, 1974 et Whitney, Elspeth, "Lynn White, Ecotheology and History », Environmental Ethics, 15, 1993, p. 151169. 
better or worse, we live in " the post-Christian age ". Certainly the forms of our thinking and language have largely ceased to be Christian, but to my eye the substance often remains amazingly akin to that of the past. Our daily habits of action, for example, are dominated by an implicit faith in perpetual progress which was unknown either to Greco-Roman antiquity or to the Orient. It is rooted in, and is indefensible apart from, Judeo-Christian teleology. The fact that communists share it merely helps to show what can be demonstrated on many other grounds that Marxism, like Islam, is a JudeoChristian heresy. We continue today to live, as we have lived for about 1700 years, very largely in the context of Christian axioms ${ }^{8}$.

Nos conclusions sur l'écothéologie - Admettons pour un instant avec White et son mouvement que l'influence des principes judéo-chrétiens perdure dans notre société laïque et qu'ils seraient par surcroît à l'origine du déclin de l'environnement que nous connaissons. Cela fait, il faut encore s'interroger sur la pertinence de solutions religieuses ou quasi-religieuses à un problème, la détérioration de l'environnement, qui concerne tous les membres de la société, que ceux-ci soient croyants, agnostiques ou athées ${ }^{9}$.

Les partisans de l'écothéologisme ne défendent pas, quoiqu'ils en disent, une véritable éthique de l'environnement puisque ce genre de doctrine devrait éviter de s'adresser uniquement et même partiellement aux croyances religieuses des personnes pour résoudre des dilemmes environnementaux. Une éthique, par définition, ne doit jamais dépendre, pour sa justification, d'un acte de foi ou d'une révélation. Il est peut-être envisageable qu'à la base de la crise environnementale, on retrouve un malaise relié à l'éthos profond (et religieux) des civilisations modernes ; il n'en est pas moins inacceptable de penser qu'une solution touchant les convictions religieuses de chacun puisse se commander à de grands ensembles sans faire inévitablement tomber ceux-ci dans l'intolérance ou le fondamentalisme. La religion ne s'impose pas. Une véritable argumentation éthique, qui cherche à produire un impact

8. White, Lynn "The Historical Roots of Our Ecological Crisis ", p. 49.

9. Par exemple, un écologiste radical tel que J. Baird Callicott, qui appelle lui aussi de ses vœux des mutations en profondeur de nos valeurs civilisationnelles concernant la Nature, soutient qu'il y a méprise chez White lorsqu'il affirme que les traits les plus marquants de la technoscience moderne proviennent de caractères liés essentiellement au judéo-christianisme. Il remarque à ce sujet : "White suggested that (....) science and technology grew, historically, out of the Judeo-Christian tradition. I have no quarrel with his historical argument, as far as it goes, but what he fails to note is that the cognitive stock-in-trade of modern science, as opposed to the warrant for undertaking it, is of Greek philosophical, not biblical religious provenance. Newton and other 17th century scientists may have been inspired by belief in a transcendent creative deity and the imago dei to try to " think God's thoughts after Him ", but the details of His supposed thoughts were inspired by Pythagoras and Democritus, not Moses and Paul. In my opinion, the more culpable conceptual roots of our ecology crisis are traceable to the intellectual legacy of Greek natural philosophy (from Thales to Aristotle), reworked by the early moderns - rather than to the intellectual legacy of the Old and New Testaments " (Callicott, J. Baird, "Genesis Revisited : Murian Musings on the Lynn White, Jr. Debate ", Environmental History Review, 14, 1990, p. 66.). 
généralisé dans une société laïque et pluraliste, doit donc s'appuyer sur des positions admissibles par tous, ce que l'écothéologisme, par définition, ne peut offrir. Et même si aux yeux des écothéologistes, la redéfinition du rapport Humain-Nature devait continuer de transiter par la spiritualité, les solutions acceptables au dépérissement de l'environnement ne le pourront pas. Ce que nous venons de dire n'exclut pas, évidemment, que des convictions religieuses puissent inciter ceux et celles qui y adhèrent à se montrer plus prévenants envers la Nature.

\subsection{L'écologie profonde : mettre fin à l'anthropocentrisme des valeurs}

Présentation - Se définissant comme une éthique véritable bien que radicale, l'écologie profonde ou deep ecology, courant initié par le philosophe norvégien Arne Naess au début des années soixante-dix ${ }^{10}$, reste à la fois la plus connue et la plus controversée des doctrines écologistes. Comme les écothéologistes, les écologistes "profonds " proposent une interprétation culturaliste de la crise écologique ${ }^{11}$. Une résolution efficace et durable des problèmes touchant à l'environnement doit s'attaquer au renversement des modalités dominantes de la tradition intellectuelle occidentale ${ }^{12}$.

Puisant à des sources de pensée multiples (en particulier des doctrines philosophiques et métaphysiques) ${ }^{13}$, les théoriciens de l'écologie profonde insistent sur l'urgence de "refaire l'unité » entre l'Humain et son milieu naturel par une "maturation des consciences » et préconisent le rejet de la mentalité individualiste et égocentrique occidentale qui aurait perverti

10. Voir notamment Naess, Arne, "The Shallow and the Deep, Long Range Ecology Movement : A Summary ", qui est généralement considéré comme le texte fondateur de l'écologie profonde (deep ecology) ; le même auteur approfondit ses thèses dans divers textes dont, parmi les plus révélateurs : Ecology, Community and Lifestyle : Ecosophy T, Cambridge, Cambridge University Press, 1987 (paru originairement en Norvège en 1975) ; aussi : "The Deep Ecological Movement : Some Philosophical Aspects ", Philosophical Inquiry, 8, 1986, p. 10-29.

11. Pour un tour d'horizon instructif des discussions portant sur ce que les écologistes profonds désignent comme les racines intellectuelles et culturelles de la crise écologique, voir, entre autres : Devall, Bill et George Sessions, Deep Ecology, Salt Lake City, Gibbs M. Smith Inc., 1985, p. 41-49 ; Ehrenfeld, David, The Arrogance of Humanism, New York, Oxford University Press, 1978 ; Fox, Warwick, "Deep Ecology : A New Philosophy of our Time », The Ecologist, 14, 1984, p. 194-200 ; Grey, William, "A Critique of Deep Ecology ", Journal of Applied Philosophy, 3, 1986, p. 211-216 ; Pepper, David, The Roots of Modern Environmentalism, New York, Routledge, 1984 ; Sessions, George, " The Deep Ecology Movement : A Review ", Environmental Review, 11, 1987, p. 105-125 ; White, Lynn, «The Historical Roots of Our Ecological Crisis ».

12. Pour une présentation claire et critique de ce projet de l'écologie profonde et une analyse de ses implications philosophiques et politiques, se référer à Ferry, Luc, Le nouvel ordre écologique, Paris, Grasset, 1992, p. 131-180 et 237-268, surtout.

13. Voir : Devall, Bill et George Sessions, Deep Ecology, p. 79-108; voir aussi : Merchant, Carolyn, Radical Ecology. The Search for a Livable World, New York, Routledge, 1992, p. 85-109. 
l'esprit humain au cours des siècles. Le but de cette entreprise réside en une volonté d'élargir la conscience humaine afin de raviver en elle le sentiment d'appartenir pleinement à la grande communauté des êtres vivants. Les tenants de l'écologisme profond souhaitent donc élaborer une nouvelle éthique pouvant infuser en chacun, indépendamment de ses croyances religieuses, la compréhension profonde que l'accomplissement de sa destinée personnelle passe nécessairement par l'acceptation de sa dépendance envers la Totalité naturelle ${ }^{14}$.

Bill Devall et George Sessions, représentants illustres de ce mouvement, écrivent à ce propos : « [f] or deep ecology, the study of our place in the Earth household includes the study of ourselves as part of the organic whole. Going beyond a narrowly materialist scientific understanding of reality, the spiritual and the material aspects fuse together ${ }^{15}$. Le deep ecologist australien Warwick Fox ajoute : " [i]t is the idea that we can make no firm ontological divide in the field of existence. That there is no bifurcation in reality between the human and the non-human realms... to the extent that we perceive boundaries, we fall short of deep ecological consciousness $»{ }^{16}$.

Pour semblable optique axée sur l'" Unité » du rapport HumainNature, il apparaît tout à fait vain de chercher à exercer une domination envers des partenaires naturels avec qui nous entretenons d'étroits rapports d'interdépendance. L'éthique proposée par la deep ecology repose essentiellement sur deux principes : la "réalisation de Soi » et "l'égalitarisme biocentrique ". La réalisation de Soi réfère à une prise de conscience de son identité dans son acception pleine et non tronquée par une focalisation exclusive sur l'ego individuel. Cette compréhension nous conduit à reconnaître que notre Soi ne peut être séparé du réseau d'échanges qui le nourrit, le forme et lui confère son sens, son identité authentique. Le principe de l'égalité biocentrique implique, pour sa part, que toutes les parties de la biosphère soient d'une même valeur, non pas comme centres isolés et individuels de vie, mais bien en tant que contributrices à la stabilité et à la diversité générales. Ces deux principes réunis interdiraient la justification de toutes formes de conflits entre les différentes entités peuplant la Nature : d'une part, « [w]e must see beyond our narrow contemporary cultural assumptions and values, and the conventional wisdom of our time and place, and this is best achieved

14. Arne Naess définit l'écologie profonde de la façon suivante : «Rejection of the manin-environment image in favour of the relational, total-field image. Organisms as knots in the biospherical net or field of intrinsic relations. An intrinsic relation between two things A and B is such that the relation belongs to the definitions or basic constitutions of $\mathrm{A}$ and $\mathrm{B}$, so that without the relation, A and B are no longer the same things. The total-field model dissolves not only the man-in-environment concept, but every compact thing-in-milieu concept - except when talking at a superficial or preliminary level of communication " (Naess, Arne, "The Shallow and the Deep, Long-Range Ecology Movement. A Summary », p. 95).

15. Devall, Bill et George Sessions, Deep Ecology, p. 66.

16. Ibid., p. 66. Propos rapportés par Devall et Sessions. 
by the meditative deep questioning process. Only in this way can we hope to attain full mature personhood and uniqueness ${ }^{17}$; d'autre part, " [t]he intuition of biocentric equality is that all things in the biosphere have an equal right to live and blossom and to reach their own individual forms of unfolding and self-realization within the larger Self-realization ${ }^{18}$. Devall et Session en concluent que :

A nurturing nondominating society can help in the " real work » of becoming a whole person. The "real work » can be summarized symbolically as the realization of « self-in-Self » where « Self » stands for organic wholeness. This process of the full unfolding of the self can also be summarized by the phrase, " No one is saved until we are all saved ", where the phrase " one » includes not only me, an individual human, but all humans, whales, grizzly bears, whole rain forest ecosystems, mountains and rivers, the tiniest microbes in the soil, and so on ${ }^{19}$.

L'écologie profonde fut l'objet de charges passablement virulentes ces dernières années l'accusant notamment de s'appuyer sur un holisme métaphysique inutilement abstrait et susceptible de déboucher sur des attitudes misanthropiques ou politiquement dangereuses. L'idée que toute la biosphère en tant qu'entité totale soit dotée d'une valeur intrinsèque surpassant celle de chacun de ses membres (y compris les Humains) engendre de vives oppositions chez ceux qui y perçoivent les germes inquiétants du retour à un romantisme globalisant et irrationnel. Marti Kheel affirme qu'une approche qui subordonne le bien de l'individu à celui de l'ensemble de la Nature devrait carrément être qualifiée de " totalitaire ${ }^{20}$. Tom Regan renchérit en affirmant que les préoccupations holistes contenues dans l'écologie profonde conduisent en définitive à une conception fascisante de l'environnement naturel ${ }^{21}$. William Aiken ajoute que les implications que recèle un tel projet sont «stupéfiantes » et « renversantes " puisqu'elles pavent la voie vers une " perte totale des droits individuels ", ce qui va à contre-courant de toute la tradition naturaliste moderne ${ }^{22}$. Dans un essai critique publié en 1992, le philosophe français Luc Ferry résume bien les nombreuses récriminations dont font l'objet l'écologie profonde et surtout ses visées holistes. Dans une envolée particulièrement acidulée, l'auteur écrit :

L'idéal de l'écologie profonde serait un monde où les époques perdues et les horizons lointains auraient la préséance sur le présent. Nul hasard, dès lors, si

17. Ibid., p. 67.

18. Ibid., p. 67.

19. Ibid., p. 67.

20. Kheel, Marti, "The Liberation of Nature: A Circular Affair ", Environmental Ethics, 7, 1985, p. 135.

21. Regan, Tom, The Case for Animal Rights, Berkeley, University of California Press, 1983, p. 372.

22. Aiken, William, "Ethical Issues in Agriculture ", dans Regan, Tom, dir., Earthbound, New York, Random House, 1984, p. 269. 
elle ne cesse d'hésiter entre les motifs romantiques de la révolution conservatrice, et ceux, "progressistes ", de la révolution anticapitaliste. Dans les deux cas, c'est la même hantise d'en finir avec l'humanisme qui s'affirme de façon parfois névrotique, au point que l'on peut dire de l'écologie profonde qu'elle plonge certaines de ses racines dans le nazisme et pousse ses branches jusque dans les sphères les plus extrêmes du gauchisme culturel ${ }^{23}$.

Nos conclusions sur l'écologie profonde - Au-delà de ces attaques sur les conséquences politiquement désastreuses de l'écologie profonde, il faut porter l'attention sur le fait que ce type d'éthique est tributaire de considérations métaphysiques, voire religieuses, qui ont assez peu à voir avec l'élaboration d'une éthique acceptable pour tous. La défense de l' "égalitarisme biocentrique » et de la "réalisation de Soi » est l'occasion de propositions qui tablent bien davantage sur la dimension intuitive et sentimentale de l'être humain que sur son caractère rationnel. Cette insistance sur l'intuitif au détriment du rationnel, les défenseurs les plus reconnus de l'écologie profonde ne s'en cachent pas :

Misunderstanding of deep ecology has resulted from assuming that its goal is to produce an ecological ethic in the sense of modern Western ethics. ( ... ) For their part, deep ecologists still use ethical vocabulary such as " rights " and " obligations" without subscribing to the modern technical philosophical theories attached to those words. Naess describes ecological egalitarianism as an intuition experienced by those in the deep ecology movement, not an ethical theory to be defended by rational argument ${ }^{24}$.

Cette position peut paraître attrayante, elle n'en va pas moins à contresens du désir d'offrir une éthique en mesure de convenir à un grand nombre puisque ses fondations demeurent trop fragiles et spécifiques. C'est ce qui fait dire à Eric Katz que :

(...) deep ecology is much less a theory of ethics than a theory of ontology and epistemology. It uses ecological thought patterns in the construction and apprehension of the world. Ecology implies a relational ontology that enables each human individual to exhibit a wider identification with all of reality; this identification leads to the central norm of the theory, the maximization of Selfrealization ${ }^{25}$.

Malgré ses intentions initiales, l'écologie profonde souffre donc du même mal que l'écothéologie : son impossibilité à faire reposer ses convictions sur des éléments moins controversés que ne peuvent l'être la religion ou

23. Ferry, Luc, Le nouvel ordre écologique, p. 180.

24. Sessions, George, "The Deep Ecology Movement : A Review ", p. 117 ; voir aussi : Naess, Arne, "Intuition, Intrinsic Value and Deep Ecology : A reply to Warwick Fox ", The Ecologist, 14, 1984, p. 201-203 et Naess, Arne, "Self Realization in Mixed Communities of Humans, Bears, Sheeps and Wolves ", Inquiry, 22, 1979, p. 231-241.

25. Katz, Eric, "Ethics and Philosophy of Environment : A Brief Review of the Major Literature ", Environmental History Review, 15, 1991, p. 85. 
d'autres intuitions aux essences holistiques ou métaphysiques sur lesquelles les Humains n'ont jamais réussi à s'entendre par le passé. Cela pose un problème majeur surtout lorsque l'on cherche à tirer des contraintes fortes qui s'appliqueront à un groupe plus large que celui des seuls adeptes déjà convaincus.

En plus des possibles égarements autoritaires maintes fois soulignés par ses détracteurs, l'écologie profonde est donc aussi hypothéquée par des postulats contestables sur "l'unité de la Nature et de l'Humain ", la " réalisation de Soi », "l'égalité biocentrique » autour desquels des sociétés le moindrement pluralistes et peuplées d'esprits libres ne pourront s'entendre facilement. La section suivante présente une alternative tout aussi « holistique » que l'écologie profonde mais qui prétend justement pouvoir répondre à cette difficulté.

\subsection{L'écocentrisme : réunir la science et l'éthique}

Présentation - L'écocentrisme prétend développer un cadre moral pourvu d'assises scientifiques et rationnelles. Cette école puise une bonne part de son inspiration fondamentale dans les travaux fondateurs de l'écologiste forestier américain Aldo Leopold, travaux qui remontent à la première moitié du $\mathrm{XX}^{\mathrm{e}}$ siècle. Elle se caractérise par une tentative de tirer des normes éthiques à partir des avancées qui ont marqué la science écologique de ce siècle. L'éthique de la terre, comme l'a qualifiée Leopold, répudie le caractère par trop individualiste et réductionniste qui empreint certains efforts (spécialement le biocentrisme dont nous parlerons plus loin) visant à conférer des intérêts moraux intrinsèques aux être naturels uniquement en tant qu'individus isolés. Les écocentristes affirment donc quant à eux qu'une compréhension adéquate des phénomènes naturels passe par une vision élargie qui ne focalise plus sur des composantes envisagées séparément, mais bien sur les "processus d'échange ", les "interrelations » et les "interdépendances » qui lient les multiples éléments des écosystèmes qui composent l'écosphère dans son ensemble ${ }^{26}$. Comme le dit Leopold : " [t] he land ethic simply enlarges the boundaries of the community to include soils, waters, plants, and animals, or collectively : the land $»^{27}$. Cela l'amène à formuler son célèbre précepte qui est devenu un véritable leitmotiv de la pensée écologiste : «A thing is right when it tends to preserve the integrity, stability, and beauty of the biotic community. It is wrong when it tends otherwise $»^{28}$.

26. Leopold, Aldo, "The Land Ethic ", reproduit dans Vandeveer, Donald et Christine Pierce, dir., Environmental Ethics and Policy Book, p. 138-147.

27. Ibid., p. 139.

28. Ibid., p. 146. 
Au cours des récentes années, les idées de Leopold ont été abondamment reprises et développées, en particulier par son interprète et continuateur le plus avoué : J. Baird Callicott. Dans un passage qui se veut une interprétation autorisée des conceptions de son prédécesseur, Callicott précise :

Ecological thought, historically, has tended to be holistic in outlook. Ecology is the study of the relationships of organisms to one another and to the elemental environment. These relationships bind the relata - plants, animals, soils, and waters - into a seamless fabric. The ontological primacy of objects and the ontological subordination of relationships characteristic of classical Western science is, in fact, reversed in ecology. Ecological relationships determine the nature of organisms rather than the other way around. A species is what it is because it has adapted to a niche in the ecosystem. The whole, the system itself, thus, literally and quite straightforwardly shapes and forms its component species ${ }^{29}$.

Empruntant la même foulée, le réputé philosophe-écologiste Holmes Rolston, III, bien que se montrant conscient du visage incongru que peuvent revêtir pour certains ces nouvelles visées éthiques écocentristes, persiste dans un article récent à en soutenir le bien-fondé :

Ethical humanists will say that ecosystems are of value only because they contribute to human experiences. But that mistakes the last chapter for the whole story, one fruit for the whole plant. Humans count enough to have the rights to flourish on Earth, but not so much that they have the right to degrade or shut down ecosystems, not at least without a burden of proof that there is an overriding cultural gain. Environmental ethics does say that ecosystems are of value because they contribute to human welfare, to animal experiences and to plant life, but it couples that with the more radical view that the stability, integrity and beauty of biotic communities are what are most fundamentally to be conserved ${ }^{30}$.

Malgré tout, les prétentions écocentristes n'ont pas cessé de prêter flanc à deux critiques récurrentes. Tout d'abord, l'idée d'une communauté biotique, méritant d'être préservée comme entité globale et constituant un réseau d'interdépendances, reste ambiguë et fait ressurgir le spectre des oppositions entre le holisme et l'individualisme. Rappelons que ces antagonismes couvrent d'importantes incidences éthiques et politiques (soumission des individus aux impératifs d'ensemble, risque totalitaire, etc.) qui rejoignent pour

29. Callicott, J. Baird, "The Conceptual Foundations of the Land Ethic ", dans Callicott, J. Baird, In Defense of the Land Ethic, New York, State University of New York Press, 1989 , p. 87.

30. Rolston, III, Holmes, "Challenges in Environmental Ethics ", dans Cooper, David E. et Joy A. Palmer, dir., The Environment in Question : Ethics and Global Issues, London/New York, Routledge, 1992, p. 144-145 
l'essentiel les accusations déjà évoquées au sujet de l'écologie profonde ${ }^{31}$. Nous n'y reviendrons pas.

La deuxième critique mérite que l'on s'y attarde davantage : l'écocentrisme raviverait, en le servant au goût du jour, le vieux débat du naturalisme en éthique que l'on avait pu croire définitivement enterré. La question est de savoir si les concepts de l'écologie scientifique moderne tels que « l'intégrité et l'équilibre des écosystèmes " peuvent servir de guide à la moralité humaine là où les notions de " loi et de finalité naturelles ", leurs ancêtres, ont échoué. En prenant pour guide de conduite les « lois de la nature » mises en lumière par l'écologie scientifique, les écocentristes se frappent à une conclusion régulièrement admise au sein de la philosophie et la science modernes depuis

31. De nombreux débats parfois très sinueux ont cours chez les spécialistes quant à l'interprétation à donner aux propos de Leopold, tout spécialement. À certains endroits (voir les extraits cités plus haut dans le corpus principal de notre texte), Leopold semble octroyer une préséance éthique à l'ensemble biotique par rapport à ses parties constituantes et considérer que c'est l'intégrité et l'équilibre de la communauté écosystémique prise comme un Tout qui constituent le point de mire ultime pour guider nos actions. Si tel est bien le cas, le risque apparaît fort que les individus (y compris humains) acquièrent une valeur simplement instrumentale et prennent ainsi leur sens essentiellement en fonction de leur contribution au bien et à l'équilibre du système dans son entier. Dans la mesure où cette interprétation prévaut, on comprend aisément que le modèle écocentriste devienne lui aussi vulnérable aux accusations estimant qu'il repose sur une logique " totalitaire » et " fasciste " en ouvrant la porte à la possibilité de sacrifier des individus lorsque l'équilibre global l'exige. Cependant, d'autres passages tirés de The Land Ethic tempèrent la première interprétation et alimentent la thèse voulant que les assertions de Leopold, lorsqu'il parle de communauté biotique, ne soient pas aussi organicistes et totalisantes que certains le laissent croire. Le ton apparaît effectivement plus nuancé lorsque l'auteur écrit, par exemple : "In short, a land ethic changes the role of Homo sapiens from conqueror of the land-community to plain member and citizen of it. It implies respect for his fellow-members, and also respect for the community as such " (Leopold, Aldo, "The Land Ethic ", p. 139). Bien sûr, cet extrait laisse poindre la possibilité que les parties conservent leur valeur individuelle dans ce modèle. Mais cela ne résout en rien l'ambiguité qui persiste lorsque l'on considère certaines situations limites où il devient impératif de trancher entre le bien d'un écosystème dans son intégrité d'ensemble, d'une part, et le bien d'individus participant à cette communauté, d'autre part. L'extrait de Callicott, précédemment rapporté, semble pour le moins accréditer la thèse à prédominance holistique et organiciste en ce qui a trait aux velléités écocentristes en général. Pour le lecteur intéressé à poursuivre la réflexion sur ce point, des discussions diversifiées et très pointues sont disponibles à travers les textes suivants : sur l'ambivalence des thèses de Léopold (Katz, Eric, " Organicism, Community and the Substitution Problem », Environmental Ethics, 7, 1985, p. 241-256); pour une évaluation nuancée du holisme et de ses implications pratiques (Marietta, Don E., « Environmental Holism and Individuals ", Environmental Ethics, 10, 1988, p. 251-258) ; sur les questions démographiques examinées du point de vue d'un écologisme holiste (Hardin, Garrett, "Lifeboat Ethics ", dans : Vandeveer, D. et C. Pierce, dir., Environmental Ethics and Policy Book, p. 378-383); pour une vision démographique plus optimiste (Simon, Julian, "Can the Supply of National Resources Really Be Infinite? Yes! », p. 401-406). 
au moins le XVIII ${ }^{\mathrm{e}}$ siècle, suivant Hume et $\mathrm{Kant}^{32}$, voulant qu'on ne devrait jamais inférer de ce qui est ce qui devrait-être ${ }^{33}$.

En confondant ces ordres épistémiques, l'écocentrisme flirte, comme plusieurs autres éthiques environnementales d'ailleurs, avec ce qu'il est convenu de nommer le sophisme naturaliste, souvent décrié par l'éthique contemporaine ${ }^{34}$. Ce sophisme est rattaché à l'idée que la Nature, prise en ce cas comme un système de finalité, puisse nous imposer d'emblée des normes éthiques. Mais comment peut-on obéir au principe de Léopold selon lequel « une chose est bonne lorsqu'elle va dans le sens de la Nature » ? Est-il même possible de s'y soumettre sans commettre des actions considérées comme proprement immorales par nos pairs ? La critique du naturalisme nous rappelle constamment que les individus humains, qu'ils le désirent ou non, demeurent quand même les seuls êtres de la Création en mesure de générer des valeurs et d'y contraindre leur comportement. Il ne faut pas chercher dans la Nature un plan de réalisation propre et indépendant auquel on devrait assujettir l'humanité.

Nos conclusions sur l'écocentrisme - Les processus naturels, quand ils sont laissés à eux-mêmes, offrent le spectacle d'un mouvement de changement perpétuel et chaotique où les équilibres stables que nous croyons percevoir deviennent bien aléatoires lorsque envisagés du point de vue de la longue durée. Prétendre qu'il faille veiller à l'équilibre, à l'intégrité ou à la diversité des écosystèmes, comme impératif éthique ultime de la conduite humaine, relève d'un pari peu convaincant tout simplement parce qu'on ne peut tirer immédiatement de la Nature aucun enseignement moral à strictement parler. Comme le souligne Janna Thompson :

Even if we focus on ecological systems, it is difficult to determine what ought to be preserved and protected and why. If we degrade an environmental

32. Voir : Hume, David, A Treatise of Human Nature, (1739) (trad. fr. : Traité de la nature humaine, Livre III : "La morale ", Paris, Garnier-Flammarion, 1993) ; Kant, Emmanuel, Fondements de la métaphysique des moeurs, Paris, Delagrave, 1967 (c1785).

33. Cette séparation étanche entre fait et valeur ou entre ordre naturel et ordre moral est cependant mise en question par les partisans d'une éthique évolutionniste qui décèlent d'importantes raisons de jeter des passerelles entre les deux niveaux de réalité, reposant notamment sur le constat que l'être humain ne peut ainsi se dissocier à volonté des cycles naturels dans lesquels il s'insère toujours. Nous suggérons de lire, entre autres, à ce propos : Hirsch, Marc, "Introduction », dans : Changeux, Jean-Pierre, dir., Fondements naturels de l'éthique, Paris, Odile Jacob, 1993, p. 11-29 et Ruse, Michael, "Une défense de l'éthique évolutionniste ", dans ibid., p. 35-64.

34. Pour approfondir la discussion concernant le sophisme naturaliste en éthique de l'environnement, il s'avère instructif de combiner différents points de vue sur le sujet. Voir en ce sens : Callicott, J. Baird, "Hume's Is/Ought Dichotomy and the Relation of Ecology to Leopold's Land Ethic », dans Callicott, J. Baird, In Defense of the Land Ethic, p. 117-127; Desjardins, Joseph, op. cit., p. 197-200 ; Rolston, III,, Holmes, « Can or Ought We to Follow Nature? ", Environmental Ethics, 1, 1979, p. 7-30; Thompson, Janna, "A Refutation of Environmental Ethics ", Environmental Ethics, 12, 1990, p. 147-160. 
system, make it less diverse, natural, stable, etc., then we have rendered it less valuable according to our criterion. But in the future this system may recover, becoming as diverse and integrated as before (though perhaps with different species), or another system just as diverse, etc. may eventually replace it (perhaps in a thousand or a million years). If we have good reason to think that this will happen, then why should we be terribly concerned about what we now do to our environment ? What counts as harm ${ }^{35}$ ?

Le sophisme naturaliste devient ici la bête noire de l'écologisme. Dans la section suivante nous verrons comment l'éthique biocentriste a tenté justement de libérer de la perspective holistique et des écueils naturalistes, tant l'écocentrisme que la deep ecology.

\subsection{L'éthique biocentriste : du holisme à l'égalitarisme individualiste.}

Présentation - Tout en s'employant à étendre l'application du lien éthique au-delà des normes régissant les rapports entre les seuls êtres humains, le courant écologiste biocentriste retient le critère de la vie biologique en vue de baliser son extensionnisme moral. Ce sont ainsi tous les êtres peuplant la biosphère, mais pris cette fois dans leur individualité en tant que porteurs d'un projet de vie bien identifiable, qui se voient gratifiés d'un statut moral. Sur ce plan, nous sommes ramenés à un critère axé sur la notion plus coutumière du respect de la vie comme pierre de touche d'une éthique de l'environnement. Cette approche permet, selon ses protagonistes, d'éviter le sophisme naturaliste en valorisant uniquement le projet de vie que déploie chaque composante de la biosphère.

L'éthique biocentriste fut principalement développée dans les travaux du philosophe Paul Taylor, depuis une vingtaine d'années tout spécialement ${ }^{36}$. Son argument principal est qu'il n'existe aucune raison décisive nous autorisant à refuser la valeur inhérente (indépendante, donc, de tout jugement normatif humain) et égale de la vie biologique en elle-même et pour elle-même, à travers la multiplicité de ses manifestations au sein de la nature. Taylor écrit en ce sens :

Respect for nature is an attitude we believe all moral agents ought to have simply as moral agents, regardless of whether or not they also love nature. Indeed, we have not truly taken the attitude of respect of nature ourselves unless we believe this. To put it in a kantian way, to adopt the attitude of respect for nature is to take a stance that one wills it to be a universal law for all rational beings. It is to hold that stance categorically, as being validly

35. Thompson, p. 157.

36. Taylor, Paul, "The Ethics of Respect of Nature ", Environmental Ethics, 3, 1981, p. 197-218 ; Taylor, Respect for Nature : A Theory of Environmental Ethics, Princeton, Princeton University Press, 1986. 
applicable to every moral agent without exception, irrespective of whatever personal feelings toward nature such an agent might have or might lack ${ }^{37}$.

Taylor considère, suivant cette façon de voir, que la possession d'une valeur en soi (of its own) ne saurait d'aucune façon s'avérer tributaire de facteurs comme la raison ou même la sensibilité, mais doit plutôt découler de la possibilité qu'un être puisse afficher un projet propre, inscrit en lui, et qui peut se déployer et se réaliser de manière autonome, sans intervention externe. Les processus vitaux rempliraient tout à fait ces conditions en actualisant les potentialités codées dans l'A.D.N., par exemple. Partant de ce constat, l'auteur estime pleinement justifié de prétendre que chaque vivant manifeste des intérêts effectifs susceptibles d'être favorisés ou contrariés. Il s'ensuit qu'une action morale adéquatement assumée ne peut légitimement faire fi de ces données et doit donc les incorporer à son univers de considérations significatives ${ }^{38}$. Dans une tirade moult fois reprise par la littérature spécialisée, Taylor affirme, prenant l'exemple du papillon : «... once we come to understand its life cycle and know the environmental conditions it needs to survive in a healthy state, we have no difficulty in speaking about what is beneficial to it and what might be harmful to it ${ }^{39}$.

On a initialement reproché à l'égalitarisme biocentrique de Taylor d'être soit contre-intuitif, soit indécidable lorsque vient le moment où il faut trancher entre des intérêts concurrents. En d'autres mots, peut-on véritablement mettre sur un pied d'égalité les intérêts humains et ceux des insectes ou même des plantes ? Qu'en est-il, par exemple, de la juste égalité entre l'intérêt, bien humain, de construire une route ou un stationnement et les intérêts des éléments fauniques et floraux qui se voient lourdement sacrifiés (mort de plantes et d'insectes, destruction d'habitats) par la réalisation de ces projets $^{40}$ ? Est-il toujours possible de respecter le principe égalitariste entre les espèces à ce moment ? Janna Thompson, une critique de Taylor et du biocentrisme, croit que non :

Taylor argues that if a thing has a good of its own, then it is a candidate for having intrinsic value. He assumes that it is individual living organisms and only individual living organisms that can have this value. But there is nothing in the criterion, or the mode of argument used to support it, that requires this limitation. It is not difficult to use Taylor's way of determining what is of value if we are to be true to the consistency requirement.

37. Taylor, "The Ethics of Respect of Nature ", dans Vandeveer, Donald et Christine Pierce, dir., p. 127.

38. Voir : ibid., p. 123-138.

39. Taylor, Respect for Nature: A Theory of Environmental Ethics, p. 66.

40. Ces difficultés sont abondamment traitées dans: French, William C., "Against Biospherical Egalitarism ", Environmental Ethics, 17,1995, p. 39-57. Voir aussi : Thompson, «A Refutation of Environmenta Ethics ", p. 147-160. 
Why can't we say, for example, that hearts, lungs, livers, and kidneys have intrinsic value and thus deserve in themselves to be objects of our moral concern ? Once we come to appreciate how a kidney or some other internal organ develops within a embryo, how it functions and maintains itself, what makes it flourish and what harms it, then surely as in the case of the butterfly or the bacteria we have to recognize that it has a good of its $\mathrm{own}^{41}$.

Conscient de ces difficultés, Taylor s'est employé à mettre au point un système de priorités ${ }^{42}$. Il s'agit en fait d'un échafaudage théorique complexe qui distingue les intérêts de base et les intérêts qualifiés de périphériques (ou de secondaires) et qui reconnaît que les intérêts vitaux (et même culturels les plus fondamentaux) d'un membre d'une espèce revêtent un caractère prioritaire lorsque confrontés aux intérêts secondaires des membres d'une autre espèce. Dans cet ordre d'idées, on admet d'emblée que des pratiques comme l'abattage des éléphants pour fabriquer des gadgets en ivoire, la cueillette de fleurs sauvages rares pour une collection privée, la capture d'oiseaux tropicaux pour la vente ainsi que la chasse et la pêche sportives doivent énergiquement se voir prohibées ${ }^{43}$. Mais ces précautions ne réussissent pas pour autant à libérer l'auteur de la nécessité d'accorder à l'espèce humaine et à ses besoins un statut particulier dans la Nature, un statut qui reste contraire à ses prétentions égalitaristes de départ (si tant est qu'elles signifient plus que de vains mots) et l'enferme, selon l'un de ses critiques les mieux informés, en pleine contradiction :

Taylor, while insisting throughout that all species have equal inherent value, sees no contradiction in allowing that even various nonbasic, human interests morally outweigh the basic interests of nonhumans. For Taylor, humans may kill animals and plants out of necessity. Humans may use animals and plants in many ways and may continue actively to develop the Earth to support our important cultural and societal values. How does this position square with his sustained, strict acceptance of species equality ${ }^{44}$ ?

Nos conclusions sur l'éthique biocentriste - Taylor continue encore aujourd'hui de récuser toute accusation d'incohérence en soulignant que son principe égalitariste doit être compris comme une norme générale, pas plus ${ }^{45}$. Cependant, pour répondre aux critiques qui lui reprochaient spécifiquement de mettre sur un pied d'égalité les êtres humains et les membres d'autres espèces, le biocentrisme réintroduit subrepticement une priorisation qui ne cadre plus du tout avec ses objectifs de départ. En faisant cela, il cède à tous ceux qui croient que les principes biocentristes sont, finalement, de peu d'utilité

41. Thompson, "A refutation of Environmental Ethics ", p. 152-153.

42. Voir à ce sujet le chapitre 6 de Respect for Nature: A Theory of Environmental Ethics, p. 256-313.

43. Ibid., p. 274.

44. French, "Against Biospherical Egalitarism ", p. 49.

45. Ibid., p. 192. 
pour trancher des litiges. Cette situation fait réapparaître cette autre difficulté qui traverse toute la littérature de l'éthique environnementale : la possibilité ou la pertinence de redéfinir la relation de l'Humain et de la Nature sans placer tout d'abord au centre de nos préoccupations le premier avant la seconde, puisque c'est de lui seul que peut provenir une réfléxion éthique et que, par surcroît, on ne peut attendre de la Nature aucun geste de réciprocité pour les attentions portées à son égard. Le biocentrisme de Taylor, comme nous venons de le voir, répond par défaut à cette question cruciale pour l'avenir de l'éthique environnementale. L'écologie politique, quant à elle, ne pourra y échapper comme nous le verrons en seconde partie.

\section{Passer de l'éthique environnementale à l'écologie politique}

\subsection{L'éthique et la politique ne sont pas coextensives}

Née d'un désir de repenser en profondeur la relation Humain-Nature, l'éthique environnementale se trouve aujourd'hui à une croisée des chemins. Confrontée à des critiques récurrentes de plus en plus vives par ses détracteurs qui remettent en question tantôt sa cohérence, tantôt ses conséquences, elle doit aussi questionner sa visée originale. Non pas que l'élucidation de ce type de question n'ait aucune valeur en soi, mais il faut bien admettre que les réponses qui lui ont été données dans le passé et celles que nous continuerons à lui attribuer dans l'avenir sont trop diverses, fragiles et incommensurables pour que nous fassions reposer l'essentiel de nos obligations environnementales sur elles ${ }^{46}$. À moins d'être imposée par la force, s'agissant en ce qui nous occupe de communautés très larges et peuplées d'individus possédant des idées extrêmement diversifiées sur le sujet, l'éthique environnementale a peu de chance de devenir une doctrine suffisamment partagée pour établir les contraintes nécessaires à la protection efficace de l'environnement.

Doit-on baisser les bras pour autant ? Pas nécessairement. Les sociétés modernes sont aux prises avec des décisions de plus en plus complexes et urgentes relatives à la protection de la Nature. Elles doivent donc pouvoir compter sur des doctrines normatives définissant des contraintes claires pour tous, en respectant le pluralisme des éthiques environnementales comme elles permettent la diversité dans les religions ou les styles de vie. C'est ce pari que doit relever l'écologie politique et que ne peuvent assumer les éthiques environnementales qui s'appuient sur des idées métaphysiques, esthétiques ou mêmes religieuses auxquelles les citoyens appartenant à une société libre ne peuvent plus espérer adhérer de manière consensuelle.

46. On pourra lire, pour un aperçu de la multitude des réponses sur le sujet: Thomas, Keith, Dans le jardin de la nature : la mutation des sensibilités en Angleterre à l'époque moderne, 1500-1800, Paris, Gallimard, 1985. 
Les commentateurs de l'éthique environnementale n'ont pas suffisamment souligné jusqu'ici la faiblesse suivante : dans une société libre et diversifiée comme la nôtre, la politique possède une certaine autonomie vis-à-vis de l'éthique et de la morale. Bien sûr, toutes deux (politique et éthique) se définissent en dernier recours par une mission normative, mais leurs champs d'application restent distincts. Les règles politiques par exemple s'adressent, dans une société qui adhère aux principes démocratiques, à des citoyens libres qui partagent des institutions communes et dont le but est de trouver des arrangements pacifiques et si possible équitables pour régir les rapports entre eux. Les institutions choisies doivent absolument avoir un pouvoir de contrainte sur tous les citoyens lorsque ce bien commun est en danger, mais elles doivent en même temps faire en sorte que chacun garde la possibilité de choisir le type de vie qu'il souhaite. L'éthique ne s'adresse pas à la condition de " citoyen ", elle possède une vocation beaucoup moins spécifique dans la mesure où elle cherche des réponses à une multitude de questions liées à l'existence humaine. Elle n'a pas obligatoirement à se montrer consensuelle, égalitaire et démocratique comme la politique qui, dans le contexte actuel des démocraties pluralistes du moins, peut difficilement y échapper, même s'il s'avère encore requis de tenter de spécifier correctement la nature de ces contraintes et la façon de les réconcilier ${ }^{47}$. Comme son champ d'application est beaucoup plus restreint, la politique ne peut, en définitive, que servir à définir certaines règles auxquelles ont inévitablement à se soumettre tous les citoyens et qui leur servent de balises dans leur relation avec des personnes avec qui ils n'entretiennent la plupart du temps aucune liaison significative. L'éthique, selon cette perspective, possède un rôle plus fondamental pour les individus puisqu'elle fournit, dans le meilleur des cas du moins, un sens et une profondeur à leur existence.

Ces distinctions cruciales que nous avons voulu introduire entre éthique et politique valent certainement pour notre relation avec la Nature. Le chapitre précédent n'a fait que présenter quelques-unes des approches éthiques possibles sur le sujet. Il en existe une panoplie d'autres qui n'ont peutêtre pas toujours retenu l'attention des philosophes mais qui n'en sont pas moins présentes, sous une forme cohérente ou non, au sein de la population. Que faire des multiples façons possibles d'envisager notre rapport à la nature?

Il faut tout d'abord admettre que plusieurs de ces éthiques, même les plus matérialistes, peuvent très bien fournir, et fournissent déjà, une argumentation en faveur de la protection de l'environnement. Même une doctrine

47. Voir : Dworkin, Ronald, Taking Rights Seriously, Cambridge, Harvard University Press, 1977 ; Larmore, Charles, Patterns of Moral Complexity, Cambridge, Cambridge University Press, 1987 ; Rawls, John, A Theory of Justice (1971), trad. fr. : Théorie de la justice, Paris, Seuil, 1987 et Political Liberalism (1993), trad. fr.: Libéralisme Politique, Paris, P.U.F., 1995. 
excessivement instrumentale ne s'oppose pas automatiquement à des mesures protectrices vigoureuses, ne serait-ce qu'en vue de préserver pour soimême et ses proches ce "réservoir de ressources " dont la qualité et la quantité peuvent se déprécier rapidement ${ }^{48}$. Cet éventail de doctrines " raisonnables » face à l'environnement doit cependant se fondre en une seule, afin que les contraintes environnementales qui pèseront sur l'ensemble de la collectivité soient les mêmes pour tous, bien sûr. Mais aussi dans le but que la justification de ces contraintes se montre suffisamment pluraliste et " œcuménique » pour qu'il devienne possible au plus grand nombre d'y adhérer. C'est à ce moment que l'écologie politique, comme complément obligé de la multiplicité des éthiques environnementales disponibles et envisageables, devient une discipline propre et en partie autonome en face de ces formes d'éthique. Non pas ici pour trancher entre ces dernières et décider laquelle est la plus "vraie ", mais plutôt pour se placer, d'une certaine façon, au-dessus de chacune d'entre elles afin de définir des principes environnementalistes qui relèvent exclusivement des obligations que des citoyens, toutes éthiques environnementales confondues, doivent mutuellement se reconnaître. En conséquence, l'éthique environnementale et l'écologie politique doivent bien sûr toujours se voir envisagées comme des doctrines normatives appliquées à l'environnement et qui jouent des rôles distincts mais potentiellement complémentaires. Nous tenterons d'expliquer dans les prochaines sections ce qu'il revient à l'écologie politique de réaliser.

\subsection{L'écologie politique doit avoir pour première préoccupation la justice.}

La justice est la vertu cardinale des institutions politiques depuis Platon ${ }^{49}$. À ce titre, elle reste essentiellement tournée vers l'établissement d'institutions et de rapports sociaux justes. Une société injuste se doit d'être réformée puisque l'injustice est par définition un affront à la coexistence pacifique entre les êtres humains, en particulier quand la vaste majorité de ceux-ci se considèrent, c'est le cas aujourd'hui, comme des individus libres et égaux. Le fait que cette valeur se révèle si importante ne signifie pas, bien entendu, qu'il soit réalisable ou envisageable de définir une fois pour toutes qu'est-ce que la justice. On est en droit, par ailleurs, d'attendre d'une théorie normative du politique qu'elle tente d'apporter des éclaircissements à ce propos, même si cela reste une réponse partielle et la plupart du temps insatisfaisante. Notre but, dans les pages qui suivent, ne sera pas de défendre une conception

48. Cette thèse a été défendue dès l'origine des débats soulevés par l'éthique environnementale écocentriste par John Passmore dans : Man's Responsibility for Nature, London, Duckworth, 1974.

49. Platon, La République, Paris, Garnier-Flammarion, 1966. 
particulière de la justice et de ses principes; nous voulons plutôt indiquer pourquoi les choix environnementaux que nous avons à effectuer ne peuvent échapper au critère de justice lui-même, quelle que soit la conception particulière de la justice sociale à laquelle nous souscrivons.

Commençons tout d'abord par nous donner une définition de la justice : dans une société moderne, la justice a pour rôle de définir la liste des libertés que devraient posséder les membres de la société ainsi que les critères selon lesquels les bénéfices et les charges de la coopération sociale devraient se voir partagés entre citoyens ${ }^{50}$. Cette définition est assez générale pour que différentes conceptions particulières, proches parentes ou radicalement opposées, puissent s'y rattacher.

Historiquement, les premiers philosophes de la justice ont cherché à débattre du statut de certaines libertés fondamentales comme les libertés politiques et celles rattachées aux droits de la personne. Plus tardivement, les préoccupations pour la justice économique furent intégrées. La conjoncture a voulu qu'il ne soit pas urgent aux XVIII ${ }^{\mathrm{e}}$ et $\mathrm{XIX}^{\mathrm{e}}$ siècles de se préoccuper de l'état de l'environnement naturel. Mais dans un monde comme le nôtre, marqué par des menaces écologiques plus prégnantes que jamais, il est devenu impératif de considérer l'accès aux ressources de la Terre de même que la sécurité environnementale comme relevant de la justice, au même titre que la redistribution des avantages économiques ${ }^{51}$.

C'est la raison pour laquelle les philosophes politiques qui se donnent aujourd'hui pour mandat de réfléchir sur la justice, qu'ils soient libéraux, libertariens, marxistes ou utilitaristes, ne peuvent éviter de penser à l'environnement sous l'angle de la distribution juste des inconvénients et avantages qui lui sont rattachés ${ }^{52}$. Peter Wenz, par exemple, qui fut l'un des

50. Nous nous inspirons ici de Rawls, A Theory of Justice.

51. Dans sa Théorie de la justice, Rawls reconnaît une liste de biens premiers qui représentent le distribuendum à répartir. Il s'agit des droits, des libertés et des possibilités offertes aux individus; des revenus ; de la richesse ; du respect de soi-même (ibid., p. 93). Des commentateurs se sont employés à inclure également les ressources naturelles comme bien social premier dont tout être humain a besoin dans la poursuite de son projet de vie. Pour un survol des tentatives d'étendre la théorie de Rawls à la justice environnementale, on lira : Manning, Russ, "Environmental Ethics and John Rawls' Theory of Justice ", Environmental Ethics, 3, 1981, p. 154-165 ; Singer, Brent A., "An Extension of Rawls's Theory of Justice to Environmental Ethics ", Environmental Ethics, 10, 1988, p. 217-232 ; Thero, Daniel P., "Rawls and Environmental Ethics : A Critical Examination of the Literature », Environmental Ethics, 17, 1995, p. 93-106. Rawls lui-même considère que sa théorie est appelée à une telle extension.

52. Pour un exemple d'interprétation libérale de nos obligations environnementales, on pourra lire : Taylor, Roger, "The Environmental Implications of Liberalism ", Critical Review, 6, 1993 p. 265-282. Pour la position des libertariens, lire : Falqué, Max et Guy Milière, dir, Écologie et liberté : une autre approche de l'environnement, Paris, Litec, 1992. Pour un exemple utilitariste, on pourra lire ; Goodin, Robert E., "Principes éthiques pour la protection de l'environnement "dans : Cragg, Wesley, dir., Philosophie - Problèmes moraux : Environnement, Montréal, McGraw-Hill, 1990, p. 63-77. 
premiers à écrire sur le sujet de la justice environnementale ${ }^{53}$, croit que l'environnement s'avère typiquement du ressort de la justice en raison des conditions qu'il fait inévitablement peser sur la qualité et le type de vie que peuvent espérer vivre un individu ou un groupe de citoyens. Il conclut que la pollution et la détérioration de la nature doivent être considérées comme un désavantage qui ne saurait être réparti arbitrairement. Personne n'a à tolérer, sans compensation, les conséquences néfastes sur sa propre vie des actions d'autrui, que celles-ci résultent de gestes volontaires ou non. La protection de l'environnement et sa détérioration éventuelle entraînent des coûts et des inconvénients à partager de manière juste parmi les citoyens ${ }^{54}$.

Si la politique a pour premier idéal la justice, alors l'écologie politique, comme discipline normative, devrait s'orienter vers la justification de critères spécifiant les droits et les obligations des citoyens en matière de protection, d'accessibilité et de sécurité environnementales. Définie de cette manière, "l'écologie politique » constitue une discipline normative qui possède inévitablement trois domaines spécifiques d'application : la justice intraétatique, la justice interétatique et la justice intergénérationnelle ${ }^{55}$.

La justice intraétatique définit le partage des coûts, des avantages ou même des risques entre des générations contemporaines cohabitant au sein d'un même territoire et possédant des institutions communes. En matières environnementales, peu de recherches empiriques ont été réalisées à ce jour sur ce plan, mais les rares études disponibles pointent clairement vers une corrélation entre niveau de revenu et qualité de l'environnement ${ }^{56}$. Les inconvénients pour les plus défavorisés peuvent aller jusqu'à des risques graves pour leur santé. Les coûts des mesures à prendre pour les protéger, eux et leur milieu naturel immédiat, doivent être pris en considération dans le calcul de faisabilité d'une initiative environnementale.

53. Wenz, Peter, Environmental Justice, Albany, State University of New York Press, 1988.

54. Outre P. Wenz, on peut lire : Cooper, David E. et Joy A. Palmer, dir., Just Environments, Intergenerational, International and Interspecies Issues, London/New York, Routledge, 1995 ; Hofritcher, Richard, dir., Toxic Struggles. The Theory and Practice of Environmental Justice, Philadelphia, New Society Publishers, 1993 ; Low, Nicholas et Brendan Gleeson, Justice, Society and Nature: An Exploration of Political Ecology, London/New York, Routledge, 1998.

55. En ce qui a trait à la justice intergénérationnelle en rapport avec les questions d'environnement, nous signalons l'ouvrage collectif récent de : Dobson, Andrew, dir., Fairness and Futurity. Essays on Environmental Sustainability and Social Justice, New York, Oxford University Press, 1999.

56. Sur l'effet distributif des politiques environnementales, on pourra lire les études empiriques de Leith, Brenda "The Social Cost of Sustainability. Distribution and Equity in Environmental Policy ", Alternatives, vol. 21, no 1, 1995, p. 18-24 ; Freeman, Myrick, « Distribution of Environmental Quality » dans Kneese, A. et B. Bower, dir., Environmental Quality Analysis : Theory and Method in the Social Sciences, Baltimore, Johns Hopkins Press, 1972 ; Peskin, H., "Environmental Policy and the Distribution of Benefits and Costs ", dans Portney, P. , dir., Current Issues in U.S. Environmental Policy, Baltimore, Johns Hopkins Press, 1978 Robinson, H. D., "Who Pays for Industrial Pollution Abatement ", Review of Economics and Statistics, 67, 1985, p. 702-706. 
La justice interétatique est le second domaine de l'écologie politique. Jusqu'à récemment, les quelques auteurs classiques en philosophie politique à avoir écrit sur la justice interétatique s'étaient préoccupés surtout des guerres et de la paix entre les États. Mais la pollution ne connaît pas de frontières et les gestes que nous posons peuvent avoir des conséquences dommageables à des milliers de kilomètres. La gestion équitable de l'environnement attend donc des débats en écologie politique qu'ils spécifient les obligations que devraient respecter entre eux les États de même que leurs citoyens afin de préserver le patrimoine mondial ${ }^{57}$.

Finalement, la justice intergénérationnelle nous oblige à nous inquiéter des effets à long terme de nos actions afin que nous ne dilapidions pas les ressources à notre disposition aujourd'hui au détriment des générations à venir. Les problèmes environnementaux se révèlent souvent des bombes à retardement et l'une des façon de justifier nos obligations pour la préservation d'un environnement sain et diversifié se situe dans la protection des besoins des autres générations ${ }^{58}$.

Ces trois dimensions de la justice environnementale devraient normalement constituer le noyau dur de toute écologie politique. Elles sont la plupart du temps interdépendantes et peuvent pour cette raison espérer un cadre d'analyse normative commun. Elles posent des questions très spécifiques, fondamentales pour la vie en société, qui laissent ouverts bien d'autres problèmes, tout aussi fondamentaux pour l'existence humaine, mais qui relèvent cette fois davantage de l'éthique environnementale que de l'écologie politique. Nous reviendrons plus loin sur ce point.

\subsection{Pourquoi l'écologie politique ne doit pas être confondue avec l'écosocialisme}

L'utilisation très particulière que nous faisons de l'expression " écologie politique » a pour objectif d'établir une distinction nette avec l'éthique environnementale. Cette proposition peut cependant rencontrer des obstacles puisque traditionnellement, particulièrement en Europe, elle fut réservée à la tradition écosocialiste de Murray Bookchin, Alain Lipietz et André Gorz ${ }^{59}$. Nous croyons qu'elle ne devrait plus en être l'apanage pour deux raisons.

57. Lire notamment Cooper, David E., et Joy A. Palmer, dir., Just Environments. Intergenerational, International and Interspecies Issues, p. 89-134.

58. Voir, entre autres, Partridge, Ernest, dir., Responsibilities to Future Generations : Environmental Ethics, Buffalo, Prometheus Books, 1981.

59. Sur cette école, on poura lire: Bookchin, Murray, The Ecology of Freedom: The Emergence and Dissolution of Hierarchy, Montréal, Black Rose Books, 1991 ; Bookchin, Murray, Remaking Society, (trad. fr. : Une société à refaire : vers une écologie de la liberté), Montréal, Écosociété, 1993 ; Lipietz, Alain, Vert espérance : l'avenir de l'écologie politique, Paris, La Découverte, 1993 ; Gorz, André, Écologie et politique, Paris, Seuil, 1978. 
La première est qu'il existe, évidemment, d'autres traditions politiques que le socialisme en mesure de se réclamer de la justice sociale et environnementale. C'est en définitive le cas de toutes celles qui, sans souscrire à la thèse écosocialiste selon laquelle la détérioration écologique a pour cause première voire unique l'organisation capitaliste du travail, n'en estiment pas moins que nos choix environnementaux exigent d'être orientés par certains principes de justice.

La deuxième raison pour ne pas réduire l'écologie politique à l'écosocialisme apparaît plus fondamentale et elle met en relief l'une des grandes faiblesses de la tradition écosocialiste. C'est que, malgré les apparences, cette dernière ne répond pas aux principaux critères de l'écologie politique. En dépit du fait que l'écosocialisme, fidèle en cela à la tradition socialiste, réfléchit en termes d'" exploitation » ou d' "aliénation ", il ne thématise pas sa propre conception de la justice sociale et se montre peu enclin à définir ses critères d'une répartition équitable du développement durable. Les écosocialistes rattachent la crise environnementale à l'exploitation capitaliste ${ }^{60}$. Ils se font plus silencieux cependant sur les raisons pour lesquelles les changements en profondeur qu'ils préconisent favoriseraient une meilleure distribution des charges et des risques. S'en remettre, comme le propose Bookchin, à la démocratie directe n'y change rien puisqu'il est bien connu que la démocratie, si elle s'avère une condition de la justice, ne nous y conduit pas inéluctablement. Ce serait alors faire preuve de laissez-faire ou d'incohérence que de présumer qu'une juste répartition découlerait d'emblée de quelque procédure démocratique que ce soit, surtout quand on demeure aussi muet que Bookchin sur notre principe de distribution! Ces critiques ne refusent pas toute pertinence à l'écosocialisme, mais elles attirent l'attention sur un élément central qui lui manque encore pour devenir une doctrine complète à l'intérieur de la famille de l'écologie politique.

\subsection{La définition de la place que l'Humain occupe dans l'ordre de la Nature ne relève pas de la justice ni de l'écologie politique.}

Nous avons défini le rôle et la tâche de l'écologie politique. Il reste à clarifier ce qui la distingue de l'éthique environnementale. On pourrait être tenté de répliquer à ce que nous avons tenté jusqu'ici que ce type d'approche, comme discipline normative, peut également se soucier de justice sociale et que la séparation que nous recherchons repose essentiellement sur une convention

60. Sur cette thèse centrale on peut lire, outre Bookchin : O'Connor James, "Capitalism, Nature, Socialism : A Theoretical Introduction ", Society and Nature, 1, 1992, p. 174-202; pour une critique des thèses écosocialistes, on pourra lire : Eckersley, Robyn, "Divining Evolution : the Ecological Ethics of Murray Bookchin ", Society and Nature, 1, 1992, p. 120143. 
arbitraire. Ce serait cependant regrettable d'aller en ce sens, tant pour l'écologie politique que pour l'éthique environnementale, qui y perdraient alors toutes les deux au change.

Notre survol des traditions en éthique de l'environnement indique clairement que celles-ci ont négligé de prendre en considération les effets distributifs des politiques environnementales. On répliquera peut-être que rien n'interdit pour l'avenir que l'éthique environnementale élargisse ses horizons à ceux de l'écologie politique. À ce moment, cependant, ses différents courants se retrouveront devant le dilemme suivant : (i) ou bien ils envisagent des principes acceptables par le plus grand nombre mais se trouvent alors forcés d'abandonner les présuppositions métaphysiques, esthétiques et religieuses qui les opposent et sur lesquelles on ne peut attendre aucun consensus parmi la population; (ii) ou bien ils maintiennent leurs prémisses mais acceptent qu'ils ne pourront pas les imposer à ceux qui ont des raisons de continuer à voir autrement l'ordre de la Nature.

Ce dilemme, au cœur de la distinction écologie politique/éthique environnementale rappelle ce qui a déjà été invoqué à la section 2.1 : on ne peut faire reposer des principes ayant un pouvoir contraignant pour tous les membres de la société sur des prémisses qui la divisent d'emblée. Reste maintenant à expliquer pourquoi il en est ainsi. La façon qui nous semble la plus éclairante de ce faire consiste à recourir à la distinction entre le Juste et le Bien que nous devons à John Rawls :

Dans une société bien ordonnée, les citoyens défendent les mêmes principes du juste et ils essaient, dans les cas particuliers, de parvenir au même jugement. Ces principes doivent établir une relation d'ordre irrévocable entre les revendications contradictoires que les individus émettent les uns à l'égard des autres et il est essentiel que cette hiérarchie soit reconnaissable par chacun, si difficile qu'il soit de l'accepter en pratique. Au contraire, les individus trouvent leur bien de façon différente et ce qui est bon pour l'un ne l'est pas nécessairement pour l'autre. En outre, il n'est pas nécessaire de parvenir à un jugement publiquement accepté sur ce qui est bon pour des individus particuliers. Les raisons qui rendent un tel accord nécessaire dans les questions de la justice ne concernent pas les questions de valeur ${ }^{61}$.

Dans une société libre qui s'efforce de distinguer ce qui relève respectivement de l'ordre du public et de l'ordre du privé, il ne faut pas exiger des doctrines qui relèvent de la justice sociale qu'elles organisent tous les aspects de la vie des citoyens. Appliqué à l'écologie politique et à l'éthique environnementale, cela signifie qu'une fois les principes de la justice environnementale posés, il reste en suspens un nombre de questions et de croyances que les éthiques environnementales pourront, à bon droit, tenter d'éclairer. La priorité du Juste sur le Bien signifie aussi que peu importe l'éthique environnementale à laquelle nous souscrivons, nous ne pourrons jamais ignorer ses

61. Rawls, A Theory of Justice, p. 487-488. Nous soulignons. 
implications distributives pour les membres de la société quels qu'ils soient. Si jamais ces implications se révélaient contraires à ce que nous dicte la justice, celle-ci devrait l'emporter en vertu des attributs mêmes du politique dans un cadre démocratique.

\section{Conclusion}

S'il est vrai que seul l'être humain demeure en mesure de porter des jugements évaluatifs sur les choses qui l'entourent, il ne s'ensuit pas pour autant que seul celui-ci puisse être objet de nos préoccupations éthiques, comme le rappelle avec insistance l'éthique environnementale. C'est en partie pourquoi cette dernière continuera de jouer un rôle légitime de sensibilisation en cherchant à convaincre le plus grand nombre d'intégrer d'authentiques valeurs écologiques dans leur vie personnelle. Mais la protection de l'environnement doit aussi être considérée, fondamentalement, comme un souci collectif en faveur de la justice sociale. Dans le but de mieux départager les rôles entre l'éthique et la politique, nous avons indiqué les raisons pour lesquelles, en cas de conflit entre l'une et l'autre, l'égalité entre les citoyens exige que l'on priorise les visées de tolérance et de justice qui devraient normalement relever du domaine politique. Cela dit, la priorité du Juste sur le Bien n'empêche d'aucune façon que le Bien puisse être complémentaire au Juste, bien au contraire. 